\title{
有機性状を考慮した有機懸濁物質の沈降速度のモデル化 \\ Modeling of Settling Velocity Considering Organic Property of Suspended Organic Matter
}

\author{
西村尚哉 ${ }^{1} \cdot$ TOUCH NARONG ${ }^{2}$ ・駒井克昭 ${ }^{3}$ ・ 日比野忠史 ${ }^{4}$ \\ Hisaya NISHIMURA, Narong TOUCH, Katsuaki KOMAI and Tadashi HIBINO
}

\begin{abstract}
It needs to estimate the accurate settling velocity of the suspended organic matter affected by the organic property in order to develop the pelagic-benthic coupled ecosystem model to evaluate coastal religion where organic mud deposits in the bottom. In this study, laboratory experiment was performed to measure the settling velocity of suspended organic matter by particle distribution analyzing for organic matters (flocks). From the results, it was cleared that the effective density decreases with increasing of particle size. Comparing with this result and its organic property, it is understood that the settling velocity is affected by the structural property strongly. And the settling velocity model considering the organic properties was suggested.
\end{abstract}

\section{1. はじめに}

沿岸域に存在する有機懸濁物質は種々の有機物が土粒 子に付着することによりフロックを形成している．さら に，有機物は沈降過程において分解が進むため，沈降速 度の決定が非常に困難であることから，一定の沈降速度 が与えられるのが一般的である. 有機懸濁物質の沈降速 度の見積もりにおいてはストークス則が用いられる場合 が多い。この場合，沈降するフロックを球と仮定し，流 体から受ける抵抗と密度差による駆動力（浮力と自重の 差）が等しいと置くことで，フロックの沈降速度 $V_{f}$ は, フロックの粒径 $D_{f}$ を用いて（1）式で表される.

$$
V_{f}=\frac{g}{18 \mu}\left(\rho_{f}-\rho_{w}\right) \cdot D_{f}^{2}
$$

ここで, $\rho_{f}$ : フロックの密度, $\rho_{w}$ : 流体の密度, $\mu$ : 流体の粘性係数, $\mathrm{g}$ : 重力加速度である.

沈降粒子を球として仮定したストークスの抵抗則から 導かれる沈降速度は, 沈降物の低抗面積 (粒径の2乗) に比例する. しかし，フロックは幾何学的構造（フラク タル構造）を有していることから，フロックの沈降速度 の測定例は，そのほとんどが粒径の $0.6 \sim 1.5$ 乗に比例し ている。例えば, Dyer・Manning（1999）のElbe河口で の測定結果ではフロックの粒径の 1 乗に比例している. 粒径の 0.6 1.5 乗に比例する要因としてFennessy・Dyer （1996）は，フラクタル構造の違いによって流速が変化 することを示している. 有機物の分解に伴う性状やフロ ック形状の変化が沈降速度に及ぼす影響については，日 比野ら（2008）が有機物と土粒子が付着した有機䀣濁物

\begin{tabular}{|c|c|c|}
\hline 1 正会員 & 修(工) & 京都府庁建設交通部 \\
\hline 2 学生会員 & & 広島大学 大学院工学研究科 \\
\hline 正会員 & 博 (工) & 広島大学助教大学院工学研究科 \\
\hline 正会員 & 博 (工) & 大学准教授大学院工学研究科 \\
\hline
\end{tabular}

質の分解を考慮し，沈降中の粒子密度と粒径を時間の関 数として定式化している. しかし，有機物の付着量や分 解が，どのような幾何学形状の有機眯濁物質を形成し， 沈降速度に影響を与えるかについては不明である.

本研究の目的は, フロック化した有機泥の沈降速度測 定法を確立し，有機性状，フロック形状をパラメータと した沈降速度のモデル化を行うことである。ここでは， 性状の異なる有機物の付着特性を表すパラメーターとし て, 幾何学的構造を考慮することで沈降速度への有機物 の付着する効果を組み入れている.

\section{2. フロックの沈降速度とフラクタル構造}

フロックを構成する粒子数 $i$ とフロック径 $D_{f}$, フロッ クを形成する個々の粒子の粒径 $d_{0}$ との関係はフラクタル 次元Dを用いて，(2) 式で記述できる.

$$
i=\left(\frac{D_{f}}{d_{0}}\right)^{D}
$$

フロックは種々の粒子が付着したものであり，個々の 粒子が直接的に付着する形状 $(D=1)$ から間隙なく球状 に付着する形状 $(D=3)$ までの付着形態が考えられる. 有効密度（沈降に有効となるフロックの占める部分と周 囲の流体との密度差） $\Delta \rho$ が，(3）式で表わされることか ら（1）式は（4）式として表わされる.

$$
\begin{aligned}
& \Delta \rho=\rho_{f}-\rho_{w}=\frac{\rho_{s}-\rho_{w}}{d_{0}{ }^{D-3}} \cdot D_{f}{ }^{D-3} \ldots \\
& V_{f}=\frac{g}{18 \mu}\left(\rho_{s}-\rho_{w}\right) \cdot d_{0}^{3-D} \cdot D_{f}{ }^{D-1} \cdots
\end{aligned}
$$

ここで， $\rho_{s}$ は構成する粒子の密度である.（1）式は全 てのフロック密度が一定であれば, 沈降速度は粒径 $D_{f}$ の 2 乗に比例することを示しているが，小さな有機泥が相 互に幾何学的に付着しているためにフロック密度がフラ クタル次元 $D$ に依存していること, 沈降速度はフロック 


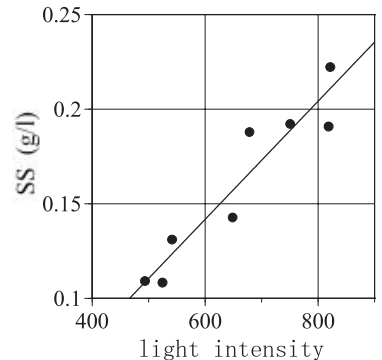

図-1ＳS と平均光強度の関係

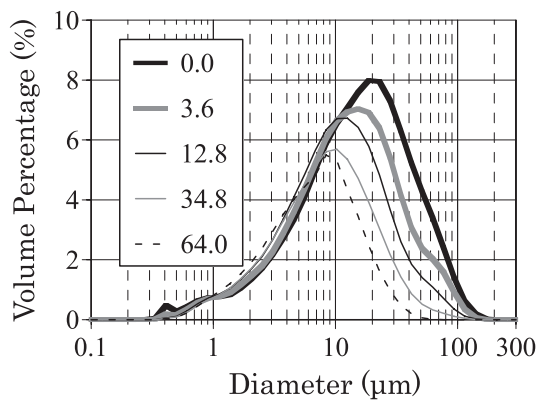

図-2 Case2の粒度分布の時間の関係変化 (凡例は測定の経過時間( $\mathrm{min})$ )

の有効密度に比例するため $D_{f}$ の $D-1$ 乗に比例することを （3）式，(4) 式は示している. 本研究では，（4）式を用 いることで, 実験で得られた沈降速度からフロックの粒 径と有効密度の特性を明らかにしている。解析では, 有 機性状から $D$ を推定し, $D$ との関係から粒径と有効密度 を推定している.

\section{3. 粒度分布の時間変化からの沈降速度の推定}

\section{（1）沈降粒子の粒度分布と残存量の測定}

レーザー回折式粒度分布計（島津製作所社製：SALD2000J）を用いて試料の粒度分布を連続的に測定すること で, 沈降により時々変化する有機㲘濁物質の粒度分布を 求めた．粒度分布の測定毎時に，レーザーを照射したと きの光の反射強度 (光強度) の平均值 (平均光強度) を 読み取った。実験では約 $10^{\circ} \mathrm{C}$ の蒸留水を用いている。測 定時間の間隔は最小で 30 秒程度, 測定時間は $30 \sim 180$ 分 である.測定に用いた試料の概要は表-1に示されている. 試料の採取は広島湾㧍よび太田川で行われた. Case.2〜 5 はセジメントトラップによる捕捉泥, Case.6はプラン クトンネットによって海面で採取したものである.

図-1に示すように, 平均光強度とSS は線形関係にあり, 測定領域内に残存する粒子量に変換することができる (最大で $\pm 0.02 \mathrm{mg} / \ell$ の誤差)。この関係を用いれば図-2 に示すように沈降によって,初期值から時間的に減少する 粒子量とその粒度分布を求めることができる.
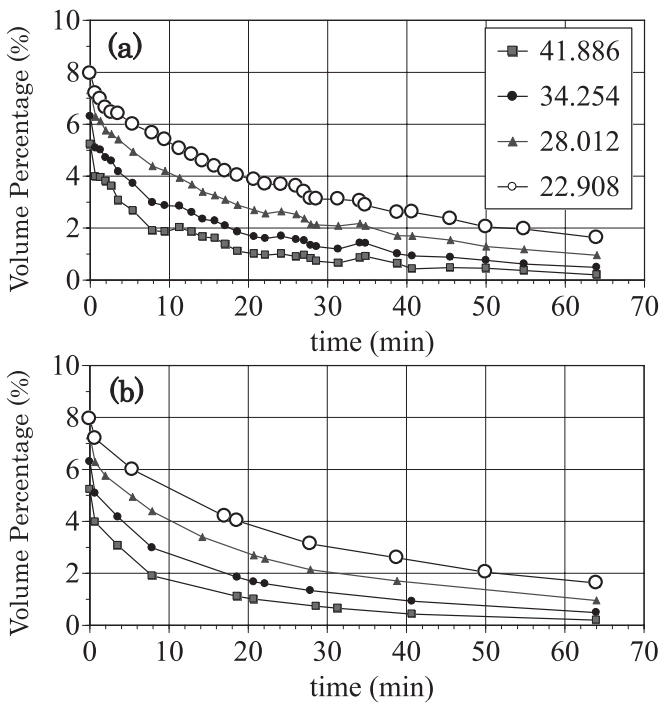

図-3 Case2の粒径別の体積割合時間変化の（a）実験値と（b） 沈降速度算出のための整理後の結果凡例は粒径 $(\mu \mathrm{m})$ を示す

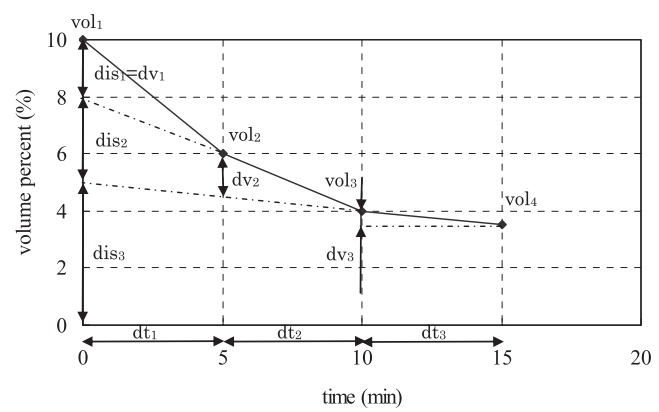

図-4 沈降速度の推定手法

（2）沈降速度の推定法

図-3にはCase2を例として粒径別の粒子体積の時間変 化を示した. 図では, $22 \sim 42 \mu \mathrm{m}$ の範囲にある4つの粒径 の体積の時間変化を示している. 同じ体積を示す粒子群 の体積変化が時間的に変化していることから, 同じ粒子 体積をもつ粒子群でも異なる沈降速度を有していること がわかる. 同径粒子群（同じフロック体積を持つ沈降粒 子）の体積の減少勾配が時間の経過とともに小さくなる のは, 同径粒子群のうち沈降速度のより遅い粒子群が測 定部に残存していくためである.

沈降速度を算出するために以下のような仮定をした。

（a）懸濁物は測定領域内において均一な分布状態から沈 降を開始する.

（b）流れによる粒子同士の干渉（衝突，粒子の分割，結 合）は無い。

(c) 最後の測定時に残留している同径粒子群の沈降速度 は測定された最も遅い沈降速度と等しい. 
表-1 実験に用いた試料の概要と解析結果

\begin{tabular}{c|c|c|c|c|c|c|c|c}
\hline \multirow{2}{*}{ Case.No } & \multicolumn{9}{|c|}{ 試料概要 } & \multicolumn{3}{c}{ 解析結果 } \\
\cline { 2 - 10 } & Category & 採取場所 & 採取位置 & IL $(\%)$ & C/N ratio & $D_{f b}(\mu \mathrm{m})$ & $\overline{\Delta \rho}\left(\mathrm{kg} / \mathrm{m}^{3}\right)$ & $D$ \\
\hline Case.1 & ベントナイ & - & - & 4.9 & 23.7 & 28 & 195 & 2.51 \\
\hline Case.2 & 沈降物 & 放水路河口 & 河床 & 9.1 & 15.5 & 34 & 31.8 & 1.64 \\
\hline Case.3 & 沈降物 & 天満川中流 & 河床 & 12.1 & 13.9 & 34 & 36.1 & 1.58 \\
\hline Case.4 & 沈降物 & 海田湾 & 中層 & 15.3 & 11.8 & 42 & 44.5 & 1.49 \\
\hline Case.5 & 沈降物 & 海田湾 & 海底 & 15.8 & 11.5 & 42 & 34.8 & 1.33 \\
\hline Case.6 & 浮遊懸濁物 & 海田湾 & 海面 & 80 & 7.6 & 42 & 13.1 & 1 \\
\hline
\end{tabular}

沈降物：セデイメントトラップ捕捉懸濁物, 浮遊懸濁物：海面表層から採取した懸濁物
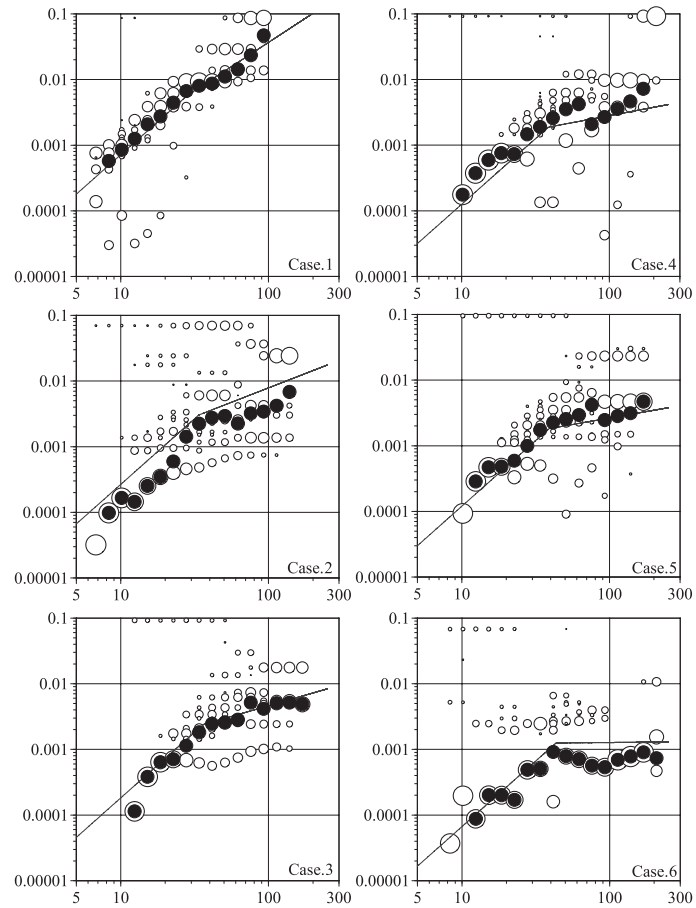

(a) 縦軸 : 沈降速度 $(\mathrm{cm} / \mathrm{sec})$, 横軸 : 粒径 $(\mu \mathrm{m})$
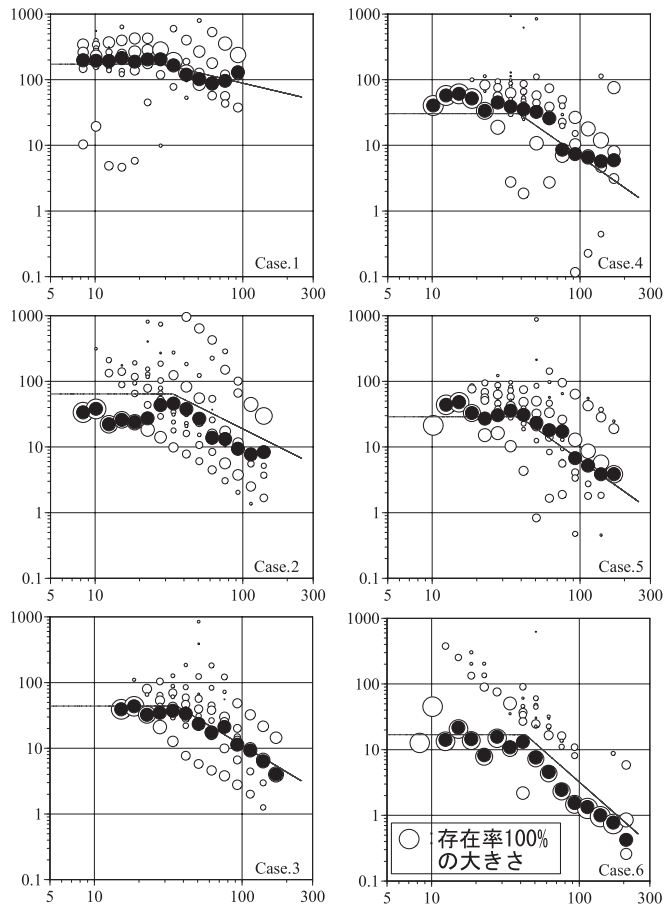

(b) 縦軸 : 有効密度 $\left(\mathrm{kg} / \mathrm{m}^{3}\right)$, 横軸 : 粒径 $(\mu \mathrm{m})$

図-5 粒径に対する（a）有効密度および（b）沈降速度の実験測定結果

（各粒径の体積頻度を○の大きさで表現, 中央值；・，モデル（(8)，（9）式）による再現值；実線）

以上の仮定に従えば，同径粒子群の残存量は沈降によ り必ず低下するため，減少勾配は小さくなる（沈降速度 の遅(粒子が残存する)。これに反するデー夕を削除す ると，図-3（a）は図-3（b）となる，図-3（b）を用いた 同径粒子群の沈降速度の算出方法を図-4に示した．図は 異なる3つの沈降速度を持つ同径粒子群 $(i=1,2,3)$ が存 在する場合を説明している。この場合，測定領域 $y$ に沈 降速度の速いものから順にdis $s_{i}$ の体積割合で存在し,その 沈降速度を $w_{i}$, それぞれの測定時間の間隔を $d t_{i}$ とすると， $v o l_{i}, d i s_{i}, d t_{i}$ は図-4 に対応する值となる．図中の $d v_{i}$ は沈 降速度 $w_{i}$ の粒子群が, $d t_{i}$ 間に測定領域外に流出した体積, 同じ流速を持つ同径粒子群の初期体積に対する流出体積
比 $d v_{i} / d i s_{i}$ は $w_{i}$ であるので領域 $y$ に対する沈降高さは $\left(d v_{i} / d i s_{i}\right) \quad y$ となる。これらの值を用いて沈降速度は（5） 式によって表される．この時， $\mathrm{vol}_{1}=d i \mathrm{~s}_{1}+d i \mathrm{~s}_{2}+d i \mathrm{~s}_{3}$ である.

$$
w_{i}=\frac{d v_{i}}{d i s_{i}} \cdot y / d t_{i}
$$

図-5に（a）粒径と推定された沈降速度との関係，(b) 粒径と（3）式から算出された有効密度との関係を示し た. 円の大きさは各粒径の体積頻度, ・は各々沈降流速 と有効密度の中央值を示している. 実線は後に示される 解析解である. 

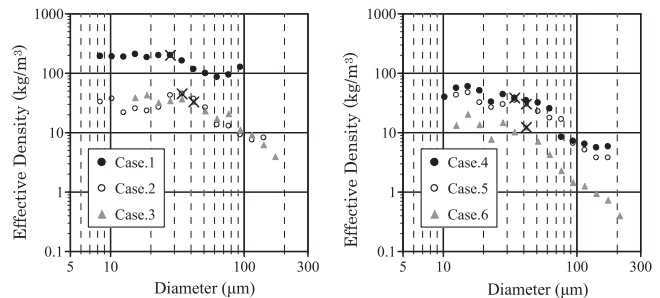

図-6 粒径とフロック密度の関係

（×は選定した粒径のプロット）
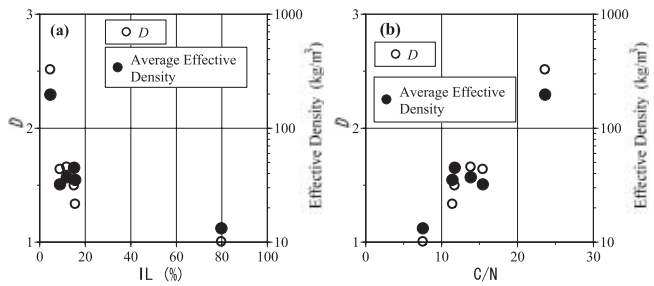

図-7 有機性状と物理特性の関係

（(a)IL，（b)C/N比とフラクタル次元および平均有効密度の関係）

\section{4. 有機懸濁物質の物理特性}

\section{（1）有効密度の減少開始粒径}

図-6には試料別の中央有効密度（図-5（b）の・）が示 されている. 粒径が $20 \sim 40 \mu \mathrm{m}$ よりも大きくなると，フ ロック密度は減少し始めるが, その粒径は試料ごとに異 なっている。これは西村ら（2008）が示した粒子径が $30 \mu \mathrm{m}$ 以下の粒子への有機物の付着量が $30 \mu \mathrm{m}$ 以上の粒子 よりも少ないことと同様の結果を示している.ここでは, この粒径を有効密度の減少開始粒径 $\left(D_{f b}\right)$ と決め, $D_{f b}$ 以下の粒径を小粒径, $D_{f b}$ 以上の粒径を大粒径とし, それ らの粒径範囲の粒子をそれぞれ小粒径粒子, 大粒径粒子 として扱う．小粒径粒子の有効密度には多少バラつきが あるが, 増加・減少傾向は顕著に現れていない. 有機物 を含まないベントナイトの有効密度は $1600 \mathrm{~kg} / \mathrm{m}^{3} て ゙ あ り ，$ 有機物が主に有機物のみで構成されていれば $500 \mathrm{~kg} / \mathrm{m}^{3}$ 程 度の有効密度となる（西村ら，2008）。図-5（b）に示す 実験值が，それらょりも小さい值を示すのはフラクタル 次元が3よりも小さいためである.

フロック径に対して有効密度が一定となるのはフラク タル次元が3のときである（(3) 式).小粒径粒子のフロ ックの有効密度が一定となっているのは, 粒径が小さく なるにつれ, 密度の小さい繊維状で保水能力の高い有機 物の付着率は高くなるが, 一方で, 小粒径粒子は粒径が 小さくなる程, 形が単純化（フラクタル次元は 3 に近づ く）するためと考えられる.これに対して，大粒径粒子 の有効密度は粒径 $D_{f}$ の増大にともなって直線的に減少し て抢り，（3）式からフラクタル次元は3未満で一定の值 をとる必要がある. フラクタル次元が一定となるのはフ

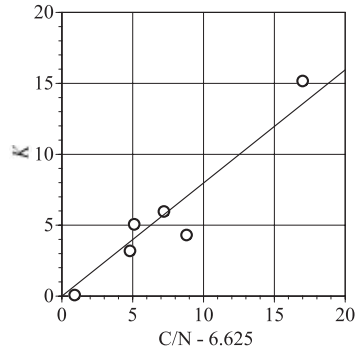

図-8 C/N比-6.625 と $K$ の関係

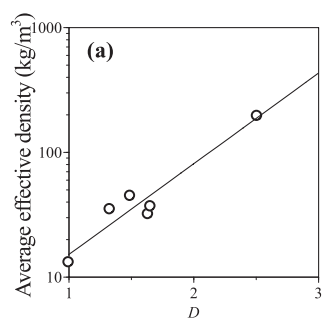

図-10 小粒径粒子の $D$ と $\overline{\Delta \rho}, D_{f b}$ の関係

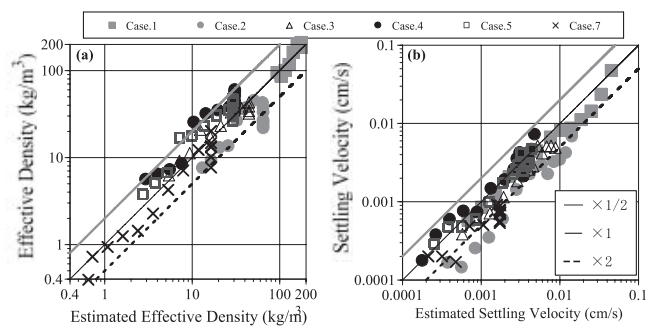

図-11 推定值と実験值の（a）有効密度, (b) 沈降速度の比較 (実験值は中央有効密度・中央沈降速度から求められており, 試料，直線とも両図で同一の凡例を用いている）

ロックの粒子構造の発達に限界があり, 有機物の特性に 応じた構造が形成されるためと考えられる。

有機懸濁物質の物理性状である $D_{f b}$, 小粒径の中央有効 密度の平均值（ $\overline{\Delta \rho}$ : 平均有効密度）および,（3）式の関 係から大粒径の $D$ を算出し, 表-1にまとめた。

\section{（2）物理特性と有機性状の関係}

図-7には（a）IL，（b）C/N比に対するフラクタル次元 および平均有効密度の関係を示している. フラクタル次 元は, ILが 0 に近づくと 3 , ILが増えると 1 に漸近するこ と, $\mathrm{C} / \mathrm{N}$ 比と線形の関係があることがわかる. また, 平 均有効密度も $\mathrm{IL}, \mathrm{C} / \mathrm{N}$ 比とフラクタル次元の関係と同様 の減少・増大傾向を示している. フラクタル次元が有機 性状に強い相関関係があることは, 前節4.（1）で考察し たフロックの粒子構造の発達が有機物の量と性状に依存 していることを示しており, 有機物量およびその分解度 が粒子同士の付着を促進または抑制することで, 構成さ れるフロックのフラクタル次元と有効密度の変動（例え ば減少開始粒径）を決定付けていると考えられる。 
実験に用いた全サンプルの IL と C/N 比には負の相関が あり， $\mathrm{C} / \mathrm{N}$ 比からだけでもDが線形に求まるが，必ずし も海域中の懸濁物の IL と C/N 比の実験に用いたサンプル 同様の相関があるわけではない. フラクタル次元の有機 物性状への依存傾向について, 次章で考察する。

\section{5. 有機性状を考慮した有機懸濁物質の沈降モデル}

\section{（1）モデルの考え方}

（a）有機懸濁物質であるフロックの沈降速度と有効密度 は, 有機物の付着量とその性状 (分解度) によって変 動する。

（b）フロックの有効密度は，小粒径では一定であり，大 粒径の場合は粒径の増大にともなって減少する.

(c) 粒径の増大に伴う有効密度の減少は, フラクタル次 元によって表される.

（d）フラクタル次元は, 有機物の付着が無い $(\mathrm{IL}=0)$ と き3であり，付着量が多くなるほど小さくなる．また， 有機物の分解度に依存する。

(e) 同径粒子に対する沈降速度の分布は有効密度によっ て決まる。

（2）フラクタル次元の推定

フラクタル次元 $D$ を有機物の付着量と分解度の関数と して（6）式で表す.

$$
D=3-2\left(\frac{I L}{I L+K}\right)
$$

ここで，Kは有機物の分解指数である.（6）式はILが

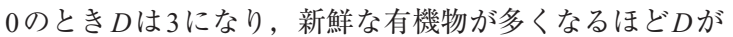
1 に漸近するという現象を表現している。一次生産され 枯死した有機物の分解度を C/N 比-6.625（6.625はRedfield 比）として表わす. C/N 比-6.625 と表-1の結果，（6）式か ら求められる $K$ には線形の関係がある（図-8）ことがわ かる.この関係から $K$ を以下の (7) 式で表す.

$$
K=0.797\left\{(C / N)_{\text {ratio }}-6.625\right\}
$$

（6）式に（7）式を代入すれば， ILと C/N 比から Dが求 まる。有機性状から算出される $D$, ILおよび $\mathrm{C} / \mathrm{N}$ 比の関 係を図-9に示す。図-9から，ILが大きくなるにつれDが 1 に漸近し，その漸近の仕方は $\mathrm{C} / \mathrm{N}$ 比にも依存している ことがわかる. ILが一定の場合， $\mathrm{C} / \mathrm{N}$ 比が大きくなると $D$ も大きくなることから，分解の進行により保水能力の 低い難分解性の有機物が残ること，または，構造的には 密な状態になることが考えられる.

\section{（3）有効密度の減少開始粒径と平均有効密度の推定}

図-10に表-1に示した小粒径 $\left(D_{f}<D_{f b}\right)$ の $D$ と $\overline{\Delta \rho}, D_{f b}$ の関係を示した。小粒径の $\overline{\Delta \rho}$ は D との関係（図-10 (a)) を指数近似することで（8）式として得られる。 $D_{f b}$ は IL と $\mathrm{C} / \mathrm{N}$ 比の関係から，主観的に決めたものであるが，IL 值が大きくなると $D_{f b}$ は小さくなり， $\mathrm{C} / \mathrm{N}$ 比が大きくなる
と $D_{f b}$ は大きくなる特性から決めることができる．Dと $D_{f b}$ は図-10（b）のように負の相関があり，これを指数近 似で（9）式のように定式化した。

$$
\begin{aligned}
& \overline{\Delta \rho}=2.83 \cdot e^{1.66 \cdot D} \cdot \\
& D_{f b}=59.1 \cdot e^{-0.30 \cdot D}
\end{aligned}
$$

沈降速度は，小粒径（ $D_{f b}$ 以下）では，（4）式に（8）式 の有効密度を代入することで得られ, 大粒径 $\left(D_{f b}\right.$ 以上) では，まず(3)式に(6)，(8)，（9)式から算出される $D$, $\overline{\Delta \rho}, D_{f b}$ を代入することで, 右辺の係数 $\left(\rho_{s}-\rho_{w}\right) / d_{0}{ }^{D-3}$ を算 出し，これを（3）式に返して粒径に対する有効密度分布 を算出する，得られた有効密度を（4）式に代入すること で沈降速度が算出できる. 図-5に本モデルから算出される 粒径に対する沈降速度の值を実線で示している．図-11に 実験值（中央值）と本モデルから算出される（a）有効密 度，（b）沈降速度の比較を示した。実験值の中央有効密 度・中央沈降速度に対して1/2 2倍の範囲で再現できた。

\section{6. おわりに}

1）沈降によって生じる粒度変化から, 有機懸濁物質 （フロック）のもつ沈降速度の分布を推定することが できた。

2）フロックの密度は小粒径では一定值であるが，有機 物の含有量と分解度に依存した粒径 $\left(D_{f b}\right)$ から, 粒径 の増加にともないフラクタル次元によって決まる勾配 でフロック密度は減少する。

3）フラクタル次元を IL と C/N 比を用いて定式化した. この関係式から，分解度への依存も確認でき，分解度 の上昇にともなってフラクタル次元が大きくなること がわかった。

4）小粒径フロックの平均有効密度と有効密度の減少開 始粒径は有機性状に依存しており，フラクタル次元に よって定式化することができた.

5）有効密度分布を表す実験式が提案され，実験值の $1 / 2$ 〜2倍の範囲で中央沈降速度を再現できた.

\section{参 考 文 献}

西村尚哉・駒井克昭・今川昌孝・日比野忠史（2008）：有機懸 濁物質の形成に関する基礎研究 一有機物の付着特性一, 海岸工学論文集, 第55巻, pp. 961-965

日比野忠史・永尾謙太郎・松永康司（2008）：有機泥の分解を 考慮した沈降と堆積過程のモデル化，土木学会論文集 B, 第 64 巻, pp. 202-213

K.R. Dyer, and A.J. Manning (1999) Observation of the size, settling velocity and effective density of flocs, and their fractal dimensions, Journal of Sea Research, Vol.41, 87-95

M.J. Fennessy, and K.R. Dyer (1996) Floc Population Characteristics Measured with INSSEV during the Elbe Estuary Intercalibration Experiment, Journal of Sea Research, Vol.36, $55-62$ 